\begin{tabular}{|c|c|}
\hline \multirow{3}{*}{ 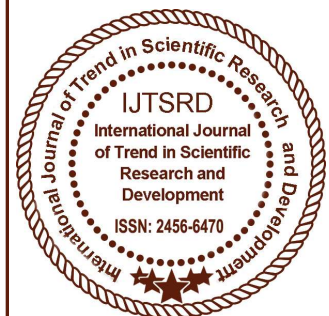 } & $\begin{array}{l}\text { International Journal of Trend in Scientific } \\
\text { Research and Development (IJTSRD) }\end{array}$ \\
\hline & International Open Access Journal \\
\hline & ISSN No: 2456 - 6470 | www.ijtsrd.com | Volume - 1 | Issue - 6 \\
\hline
\end{tabular}

\title{
The Effect of Demonetization on the various Sectors
}

\author{
Dr.K.Suryanaryana \\ Associate Professor, Department of Management \\ Scieces, R.V.,R\&J.C.CollegeEnggineering, \\ Chowdavaram, Guntur
}

\author{
Dr.T.Sreekrishna \\ Associate Professor, Department of Management \\ Sciences, R.V.,R \&J.C.CollegeEnggineering, \\ Chowdavaram, Guntur
}

\begin{abstract}
In an emboldened move, government declared that the 500 and 1000 Rupee notes will no longer be legal tender from midnight, 8th November 2016. The RBI will issue new Rs. 500 and Rs. 2,000 notes which will be placed in circulation from 10th November 2016. Notes of 100, 50, 20, 10, 5, 2 and 1 Rupee will remain legal tender and will remain unfazed by this decision. This measure has been taken by the prime minister if India in an attempt to address the resolve against corruption, black money, terrorism and counterfeit notes. This move is expected to cleanse the formal economic system and discard black money at the same time. One of the reasons that prompted the Government to demonetize Rs. 500 and Rs. 1000 notes is that their circulation was not in line with the Economic Growth. As per the Finance Ministry, during 2011-2016 periods, the circulation of all notes grew $40 \%$ but the circulation of Rs. 500 and Rs. 1000 notes went up by $76 \%$ and $109 \%$ respectively. Relatively speaking, the economy has grown only by $30 \%$ which is way below the money circulation.
\end{abstract}

At an aggregate level, this move will significantly eliminate the existing stock of black money, fake currency and will benefit the economy in the mediumto long-run, but, the question as to how the creation of black money in the future will be prevented still remains unanswered.
Objectives of the Study

1. To understand the impact of demonetization on institutions, agriculture, FMCG, airlines etc.,

2. To analyze the impact of demonetization on the economy.

3. To understand the reasons and the outlook of the demonetisation in various sectors.

\section{Research Methodology}

The process of research methodology is used to collect information and data for the purpose of making business decisions. The methodology may include publications research, interview, surveys and other research techniques, and could include both present and historical information.

In this research secondary data is used for understanding the objectives and to collect the data, mainly online resources are utilized.

\section{Impact on different Sectors}

The impact of this move will be felt across sectors with differing intensities and across varied time zones.

1) Effect on parallel economy: Cash Economy to Witness Contraction

The currency of the aforementioned denominations constitutes around $86 \%$ of the total value of the 
currency in circulation. It is expected to remove black money from the economy as they will be blocked considering the holders will not be in a position to deposit the same in the banks, temporarily halt the circulation of large volumes of counterfeit currency and curb the funding for anti-social elements like smuggling, terrorism, espionage, etc.

\section{2) Effect on GDP: Downward Bias to GDP Growth}

The sudden decline in money supply and simultaneous increase in bank deposits is going to adversely impact consumption demand in the economy in the short term. This, coupled with the adverse impact on real estate and informal sectors may lead to lowering of GDP growth.

The GDP formation could be impacted by this measure, with a reduction in the consumption demand. However, with the recent rise in festivals, demand is expected to offset this fall in an overall impact. Moreover, this expected impact on GDP may not be significant as some of this demand will only be deferred and will re-enter the stream once the cash situation becomes normal.

Lower Money Supply has a Deflationary Effect: With the older 500 and 1000 Rupees notes being scrapped, until the new 500 and 2000 Rupees notes get widely circulated in the market, money supply is expected to be reduced in the short run. Reduction in money supply can also have a deflationary effect in the economy. However, whether the impact of the reduced money supply will lead to deflation or contraction in demand or a mix of both will vary from sector to sector depending on the nature of goods \& services. To the extent that black money (which is not counterfeit) does not re-enter the system, reserve money, and eventually, money supply will decrease permanently. However, gradually as the new notes get circulated in the market and the mismatch gets corrected, money supply will pick up speed.

Impact on Bond Markets: Surge in deposits will create more demand for government bonds and other high rated bonds in a situation of demands for credit, leading to lower bond yields especially in the shorter end of the curve. At the same time, a reduction in leakages in systemic liquidity will reduce the scope for open market operation purchases in the coming days. RBI will continue to sterilize excess liquidity from the banking system to keep the short term rates aligned with the policy rate.

Credit Impact across Sectors: Impact of this policy measure will flow to the economy mainly through the Real Estate sector, which has strong linkages with sectors such as cement and steel and which will turn credit negative in the short-run. A significant impact in the short-run will be on the daily/weekly wage employment in the informal sector. The construction sector has one of the highest employment multipliers. The key segments of the economy where cash transactions play a vital role are real estate, gold and the informal sectors, which may face near term contraction. With more money coming into the banking ambit, deposit growth is likely to improve and positively impact the savings rate. The mediumto long-term gains are likely to outweigh the shortterm pains.

\section{3) Effect on Banks}

As directed by the Government, the 500 and 1000 Rupee notes, which now cease to be legal tender are to be deposited or exchanged in banks (subject to certain limits). This will automatically lead to more amounts being deposited in Savings and Current Accounts of commercial banks. This, in turn, will enhance the liquidity position of the banks, which will be later utilized further for lending purposes. However, to the extent that households have held on to these funds for emergency purposes, there are expected to be withdrawals at the second stage.

Development of Online Transactions and alternative modes of payment: With cash transactions facing a reduction, alternative forms of payment will see a surge in demand. Digital transaction systems, E wallets and apps, online transactions using E banking, usage of Plastic money (Debit and Credit Cards), etc. will definitely see substantial increases in demand. This should eventually lead to strengthening of such systems and the infrastructures required.

Bank Deposit Rates to Soften: A large amount of cash in circulation to be brought within the purview of the formal banking system by way of deposits. This is structurally positive for banks, as part of this cash gets deposited as current account and savings account (CASA) deposits, reducing banks dependence on higher cost borrowing. Deposit deployment remains a 
challenge in the short to medium term due to the current tepid demand for credit, subsequently pushing deposit rates lower.

NBFC's Asset Quality Faces Pressure: The asset quality of Retail Asset Lenders, especially NBFC's which have developed expertise in the credit assessment of the informal segment and have built models around it to stay under pressure in the short term. Within NBFC's, asset quality of lenders with a large dependence on cash collection remain vulnerable in the short term. In the longer term the implications could be a risk profile shift for the NBFCs, as the stronger borrower profile could potentially migrate to banks. Across the medium term, the demand for real estate, especially in the secondary market i.e. Resale Transaction and Tier-II cities where the cash component, as a proportion of transaction is significant could face a slowdown. This trickle-down effect could encompass the entire real estate sector putting pressure on the demand itself. This could adversely impact NBFC's \& housing financers with a large proportion of exposure Mortgage built with a self-employed customer profile. We believe that Micro Finance Institutions and Small Finance Banks (SFB's) may not be significantly impacted in the long term, considering that the cash flows of the borrower segment are usually in the smaller denomination. However, there could be near term disruptions in the collection cycles along with a spike in over dues, which could put their liquidity strengths and the disbursal cycles under pressure.

Investment in Financial Products: Investors in the short term will now believe that Cash is not the safest asset and there is little point in hoarding it. This will shift them from physical asset to financial assets where returns are also higher

\section{3) Impact on Consumption Sectors}

Agreement Cost of Real Estate May Rise: The real estate demand from end users is unlikely to be impacted, since a majority of them are backed by funding from bank loans. Demand from investors for real estate however may come down since in some cases, investors prefer cash transactions. If the proportion of earlier transactions in the real estate sector, which were allegedly done through partial cash payment reduces, the registered prices for real estate will go up. We expect the supply of real estate in the secondary market, which is strongly rumored to have a large cash component involved, to suffer in the short term, which may in turn improve demand for residential real estate in the primary market.

In the medium term, the prices in this sector could regain on many fronts as developers rebalance their prices (probably charging more on cheque payment).

Used car Sales May Fall: Sales of vehicles in the second hand market for original equipment manufacturers will get impacted, which will cause a ripple effect on New Car sales, as buyers will not be able to dispose of their old vehicles easily.

Slowdown in Discretionary Spending to Hurt Consumer Durable Sales: Sales of White Goods like TV, Refrigerator \& Washing Machine could slump as much as $70 \%$ as a good portion of the market is driven by Cash. This may continue for next Six Months till the dust settles down and there is adequate circulation of the new currencies.

Prices are expected to fall only marginally, due to moderation in demand, as use of cards and cheques could compensate for some purchases.

High End Retail Demand to fall: The impact on high end fashion retail and luxury goods to be more pronounced as discretionary demand in this segment will be curtailed. In case of Quick Service Restaurants, although $60 \%-70 \%$ of the transactions are currently in cash, the impact is likely to be moderate due to the low ticket size of purchases and high likelihood of patrons adapting to plastic money. We expect a limited impact to be caused on the food and grocery retail sub-segment, given the nondiscretionary nature of purchases in this segment, since the buying cycle for the current month would have been largely influenced.

Private Educational Institutions: Since Private Educational Institutions take huge amounts of donations in Cash which is $40 \%$ to $50 \%$, we expect that this move will impact the Private Education Institutions receipts.

Medical Institutions (Both Hospitals \& Medical Colleges): Again, as Medical Institutions like Hospitals and Colleges take huge amounts of donations in Cash which are more than $100 \%$ of fees, we can keep on expecting that this move will impact not only the admissions but also the receipts. 
Political Parties: Elections \& Political Parties are major sources of Black Money transactions. Most of the funding of National Political Parties is in Cash which is $40 \%$ to $50 \%$, and when it comes to Regional Parties it goes upto $50 \%$ to $60 \%$. The sources of more than $90 \%$ of such funds are never disclosed. Candidates as well as their donors even the Political Parties will feel cash strapped. An assembly seat candidate spent on an average Rs. 4-5 Crores on Campaigning that is likely to go down drastically.

This is going to cause huge craters on their funding and will reduce their funds drastically. It is going to deal a major blow to political parties fattening their coffers with cash contributions in anticipation of high stakes electoral battles in UP, Punjab, Uttarakhand, Goa and Manipur. This stroke is bound to leave big players hamstrung and suddenly resource-poor.

\section{4) Effect on various economic entities}

The key segments of the economy where cash transactions play a vital role are real estate / construction, gold and the informal sectors as such. The role of cash transactions in case of real estate and gold is mostly dubious, however in case of the informal sectors it is the lifeline. For example, small and marginal farmers in the fruits and vegetables category typically require off-loading of their produce in the local Mandi in cash and could see an immediate impact. A sudden demonetization will adversely impact this segment of the economy and it will witness immediate contraction, though this impact will diminish over time.With cash transactions lowering in the short run, until the new notes are naturalized widely into circulation, certain sections of the society could face short term disruptions in facilitation of their transactions. These sections are:

$>$ Agriculture and related sectors

$>$ Small traders

$>\mathrm{SME}$

$>$ Services Sectors

$>$ Households

> Professionals like doctors, carpenters, utility service providers, etc.

$>$ Retail outlets

The nature, frequency and amounts of the commercial transactions involved within these sections of the economy necessitate cash transactions on a more frequent basis. Thus, these segments are expected to have the most significant impact post this demonetization process and the introduction of new notes in circulation.
$>$ Since most of the Rural Economy is based on Cash, it's going to impact the Rural Economy

$>$ Sectors with a sizeable magnitude of Cash transactions such as Real Estate, Construction, Jewellery, high-end retail, White Goods and travel \& tourism are expected to adversely affect.

$>$ It will push the economy because of flow of more money into the banking system.

$>$ In the long term, the economy will benefit from the reduction of the black money, which will lead to higher tax collection, better business environment, less corruption \& transparency. It will improve the situation of Fiscal Deficit of the Country and hence reduce the fiscal deficit.

\section{5) Impact on the rights of individual citizens}

One problem with a cost-benefit approach is that, unless it is done very carefully, it can justify inflicting a great deal of pain upon innocent people just so that society in the aggregate can benefit. Even when done carefully, it is still based on the utilitarian assumption that as long as a decision is beneficial in the aggregate, it can be justified. This aggregate net benefit is a necessary condition for a decision, but is it a sufficient condition. In a totalitarian system, where individual identity is subsumed under the collective good, aggregate benefit is both a necessary and sufficient condition. However, in a democratic republic, individual rights and duties provide the foundations on which democratic self-government is established and sustained. Civil and economic rights must be preserved, even in face of aggregate societal benefits. For example, a poor person may not contribute much to the GDP, but is still a citizen who has a piece of the constituent power that established the state in the first place. Any consideration of costs and benefits must be over and above an understanding of the rights of individuals that cannot be taken away.

The decision to discontinue the Rs. 500 and Rs. 1000 notes is harmful for the economic liberties of citizens. For weeks, their ability to conduct their economic lives has been severely disrupted. Money is of no use if one cannot use it when one needs to. By restricting withdrawals from banks, which is a decision of questionable legality, and by limiting exchange of notes, people have been deprived of using their hardearned money when they need it. Because of the 
restrictions, some may be forced to take losses even on their hard-earned money.

The decision has led to considerable problems for people who needed cash for an emergency, for a preplanned social event, or for other legitimate purposes. This is an insulting way to treat citizens, and potentially infringes upon their other rights. Their ability to take care of their health, to move across the country, to practice their profession, etc, are affected by this abrupt decision. Many of these impacts are not fully captured in a simple cost-benefit analysis.

\section{6) Impact on institutions}

Institutions are not just their buildings, people or statutory powers. They are ideas that exist in the minds of people. The RBI has earned its credibility over more than 80 years, maintaining an image of an independent organisation that values integrity. There are criticisms of the RBI that it may have become hostage to its own success, and now stands in the way of India's progress in macroeconomics and finance. However, its legitimacy and integrity have almost never been questioned. Now, the same institution has been placed in a very difficult position. The way this decision was presented and is being implemented, there is cause to suspect that institutional distinctions were ignored, except as mere formalities. The government's messaging is not helping the matter. Some in the government are crediting its leadership for the idea, while others are saying that it was the RBI's idea. Communications about all matters are centralised at the ministry of finance, even regarding matters in the RBI's jurisdiction. This episode is harmful to the efforts to portray the RBI as an independent central bank. Add to all this the drama around badly printed notes, faulty drafting of notifications, and poor communications from the central bank, and we may have the beginning of the end of an institution's credibility.

Four decades later, the capitulation of the judiciary during the Emergency still looms large in our imagination of that institution's ability to protect our rights in our darkest hours. This note ban episode threatens to similarly cast a long shadow upon macroeconomic and financial policy in India. This episode indicates the limitations of legal protections such as statutory independence, job security under Article 311 of the constitution, etc. The vaunted checks and balances appear to be inadequate. The constitutional design of dividing power and vesting it in multiple institutions has been revealed to have severe limitations in practice, especially when a powerful government sets its mind to do something. Another long-term institutional impact of this decision would be seen in the increase in the draconian powers of tax authorities. The nature of power of tax authorities is such that effectiveness can only be achieved by a complex system of accountability. Maximising revenue is not necessarily the best objective, as it may lead to abuse of power. The recent announcements seem to suggest that the tax department, especially their enforcement officials, will be given a carte blanche to go after depositors of cash. Since this is a high priority for government, they might err on the side of excess. Some may abuse their powers for personal gains. The damage to the institution would be lasting, and it might take a long time to restore a sense of balance and accountability.

The following table 1 shows the impact of demonetization on various sectors and the reasons of the impact and the outlook. 
Table 1

Sector Wise Analysis of Demonetization

\begin{tabular}{|c|c|c|}
\hline SECTOR & REASONS & OUTLOOK \\
\hline $\begin{array}{l}\text { REAL ESTATE } \\
\text { IMPACT: } \\
\text { NEGATIVE }\end{array}$ & $\begin{array}{l}\text { Developers and consultants say that home } \\
\text { sales have slowed down significantly as } \\
\text { consumers defer home purchases. Land } \\
\text { transactions are at a standstill. Developers } \\
\text { have deferred launches of premium projects } \\
\text { while prices of land and properties, } \\
\text { particularly luxury homes, are likely to drop } \\
\text { in the next } 3-6 \text { months. Even secondary } \\
\text { (resale) property markets sales have dropped } \\
\text { by } 50 \% \text {, say brokers and analysts. }\end{array}$ & $\begin{array}{l}\text { : While the short-term impact is negative, } \\
\text { developers expect things to return to } \\
\text { normal over the course of the fiscal year. } \\
\text { Some are hoping that rate cuts in the } \\
\text { coming months would boost home sales. }\end{array}$ \\
\hline $\begin{array}{l}\text { BANKS } \\
\text { IMPACT: Mixed } \\
\text { over short-term, } \\
\text { neutral to positive } \\
\text { in the long term }\end{array}$ & $\begin{array}{l}\text { A big surge in low-cost deposits will help } \\
\text { banks in the short-term. It means lower cost } \\
\text { of funds and better margins. The rise in } \\
\text { balance sheet size will also help when credit } \\
\text { growth picks up. As yields fall, owing to } \\
\text { excess liquidity, banks stand to book } \\
\text { treasury gains too. However, on the flip } \\
\text { side, loan disbursements are stagnating. } \\
\text { With production estimates reduced, there is } \\
\text { no need for working capital either. Lenders } \\
\text { will be hard pressed to find incremental } \\
\text { credit demand even during the busiest of the } \\
\text { seasons. And asset quality could worsen as } \\
\text { the economy slows. }\end{array}$ & $\begin{array}{l}\text { Non-interest income for banks would } \\
\text { increase, but asset quality and credit } \\
\text { growth will be hit in the short-term. Over } \\
\text { the long term, demonetisation should } \\
\text { benefit banks because they will likely } \\
\text { attract a disproportionate share of savings } \\
\text { and see greater fee income from electronic } \\
\text { payment opportunities. }\end{array}$ \\
\hline $\begin{array}{l}\text { CONSUMER } \\
\text { PACKAGED } \\
\text { GOODS: }\end{array}$ & $\begin{array}{l}\text { Consumers have cut back on discretionary } \\
\text { spending. The whole business has been hit } \\
\text { because it is largely dependent on cash. The } \\
\text { traditional trade has been hit hard, especially } \\
\text { wholesalers and kirana stores where } \\
\text { transactions are largely in cash. Still, things } \\
\text { are recovering; sales are now down only } 20 \text { - } \\
25 \% \text { on a year-on-year basis compared to } \\
50 \% \text { in the first week after the note ban. } \\
\text { Rural sales have been hit more }\end{array}$ & $\begin{array}{l}\text { Third quarter numbers for packaged } \\
\text { consumer goods sellers will be severely hit, } \\
\text { despite the wedding and holiday season. In } \\
\text { the long term, things should bounce back } \\
\text { as the economy is re-monetized, and firms } \\
\text { lower in the supply chain too move to non- } \\
\text { cash payments. }\end{array}$ \\
\hline $\begin{array}{l}\text { IMPACT: } \\
\text { Negative }\end{array}$ & $\begin{array}{l}\text { There has been a significant impact on } \\
\text { inbound travel. Some airlines have seen } \\
\text { bookings go down by about } 16 \% \text { in the } \\
\text { week after demonetisation compared to the } \\
\text { one before that. Discretionary travel has } \\
\text { been the worst hit. Poor sales have forced all } \\
\text { airlines to bring forward their airfare sales- } \\
\text { usually reserved for the low season starting }\end{array}$ & $\begin{array}{l}\text { Because fuel prices have been low, airlines } \\
\text { have been able to fill seats by offering } \\
\text { cheaper fares but the real impact of } \\
\text { demonetization will be visible in } \\
\text { December, January and February when the } \\
\text { final revenue and traffic numbers are } \\
\text { released. }\end{array}$ \\
\hline
\end{tabular}




\begin{tabular}{|c|c|c|}
\hline & $\begin{array}{l}\text { January. International traffic to West Asia } \\
\text { and South-East Asia, especially by traders } \\
\text { and low-wage workers, has been hit. } \\
\text { Business jet operators say several charter } \\
\text { flights have been cancelled as payments are } \\
\text { often made in cash. }\end{array}$ & \\
\hline $\begin{array}{l}\text { AUTOMOBILES } \\
\text { IMPACT: } \\
\text { Negative }\end{array}$ & $\begin{array}{l}\text { Demand has been hit. Most firms expect to } \\
\text { see a decline in sales. In two-wheelers, } \\
\text { where transactions are through cash, sales } \\
\text { have taken a massive hit. Hero MotoCorp } \\
\text { Ltd, for instance, sold } 480,000 \text { units in } \\
\text { November, down from a monthly average of } \\
600,000 \text { units }\end{array}$ & $\begin{array}{l}\text { It will take a while for demand to improve, } \\
\text { say dealers, but the good part is that } \\
\text { enquiry levels have not dropped and that } \\
\text { suggests it is a matter of time, may be three } \\
\text { months, before the industry gets back on } \\
\text { track. }\end{array}$ \\
\hline $\begin{array}{l}\text { PHARMA } \\
\text { IMPACT: } \\
\text { Negative for now, } \\
\text { neutral over the } \\
\text { long term }\end{array}$ & $\begin{array}{l}\text { Pharmaceutical product sales likely fell 8- } \\
10 \% \text { month-on-month in November with } \\
\text { sales of medicines for acute diseases feeling } \\
\text { the adverse impact of demonetisation due to } \\
\text { lower patient turnout, although retail sales } \\
\text { of medicines for chronic diseases rose in the } \\
\text { first fortnight, as patients stocked up } \\
\text { medicines by using old notes at pharmacies, } \\
\text { which were among the few outlets accepting } \\
\text { old banknotes. Offtake from wholesalers } \\
\text { and stockists was sluggish and companies } \\
\text { have extended the credit period by 7-21 } \\
\text { days. }\end{array}$ & $\begin{array}{l}\text { Owing to advanced buying of medicines } \\
\text { for chronic diseases and seasonally weak } \\
\text { December-March period for the industry, } \\
\text { sales of drugs are expected to remain } \\
\text { subdued. The impact of demonetisation on } \\
\text { the sector is likely to be temporary as } \\
\text { demand for drugs is largely inelastic but } \\
\text { the growth rate in the coming months may } \\
\text { be slower than the } 9-10 \% \text { witnessed in the } \\
\text { first } 6-7 \text { months. }\end{array}$ \\
\hline
\end{tabular}

\section{CONCLUSION}

In this context, direct democracy is suitable for certain local issues where people can see the inputs and outcomes. For complex, macro issues, legislators and governments may seek public opinion (perhaps through opinion polls), but then they must exercise their own judgment. People demanded an attack on black money, but they did not demand demonetisation as the weapon of choice. When asked, people seem to be saying that they support the move, perhaps because they believe that it is worth trying, when other measures don't seem to have worked. However, leaders are in the arena and they must also hold their decisions to other measurable standards of success. Popularity does not necessarily attest to soundness of a policy. It is for the leaders to exercise judgment in devising the least expensive and most effective ways to attack generation and storage of black money.

\section{REFERENCES}

1. www.bloomberg.com

2. https://thearcmag.com/indias-demonetizationexplained-6092a70d964d

3. www.reuters.com

4. www.forbes.com 